\title{
Differential behavior of the summer cover crops in the absorption and translocation of copper
}

\author{
Diogo Vendruscolo ${ }^{-\infty}$ Natielo Almeida Santana ${ }^{2}$ \\ Kelen Müller Souto ${ }^{2}$ Paulo Ademar Avelar Ferreira ${ }^{2}+$ \\ George Wellington Bastos de Melo $^{3} \odot$ Rodrigo Josemar Seminoti Jacques ${ }^{2 *}$
}

${ }^{1}$ Associação Riograndense de Empreendimentos de Assistência Técnica e Extensão Rural (EMATER/RS), Pinhal Grande, RS, Brasil. ${ }^{2}$ Departamento de Solos, Universidade Federal de Santa Maria (UFSM), 97105-110, Santa Maria, RS, Brasil. E-mail: rodrigo@ufsm.br. "Corresponding author.

${ }^{3}$ Embrapa Uva e Vinho, Bento Gonçalves, RS, Brasil.

\begin{abstract}
Phytoremediation is an alternative technique used to treat copper-contaminated soils. The objective of this research was to explore the behavior of nine summer cover crops regarding the growth, absorption and translocation of copper in soils with contamination levels exceeding the Value of Prevention, with a view to selecting plants for phytoremediation programs. In the experiments the Cambisol was contaminated with copper, added in doses of 0, 100, 200, 400, 500 and 600mg $\mathrm{kg}^{-1}$, in which the following nine plants were cultivated under greenhouse conditions: Canavalia ensiformis, Cajanus cajan, Dolichos lablad, Mucuna cinereum, Mucuna aterrima, Crotalaria juncea, Crotalaria spectabilis, Pennisetum glaucum and Paspalum notatum. At 90 days after sowing the plants were evaluated for dry mass of shoot and root, $\mathrm{Cu}, \mathrm{N}, \mathrm{P}, \mathrm{K}, \mathrm{Ca}, \mathrm{Zn}$, and Fe levels in the shoot and $\mathrm{Cu}$ in the roots. High soil Cu levels induced a decline in the phosphorus absorption by the plants. Canavalia ensiformis displayed high potential for phytoextraction as these plants could translocate high copper concentrations to the aerial plant parts, while the Mucuna cinereum and M. aterrima are indicated for the copper phytostabilization programs, due to the high copper accumulation in their root systems.
\end{abstract}

Key words: heavy metal, soil pollution, phytoremediation, phytostabilization, phytoextraction.

Comportamento diferencial das plantas de cobertura de verão na absorção e translocação do cobre

RESUMO: A fitorremediação é uma alternativa para o tratamento de solos contaminados com cobre. O objetivo do trabalho foi conhecer o comportamento de nove plantas de cobertura de verão quanto ao crescimento, absorção e translocação do cobre em solos com contaminação acima dos Valores de Prevenção, com vistas a seleção de plantas para programas de fitorremediação. Um Cambissolo foi contaminado com doses de 0, 100, 200, 400, 500 e 600 $\mathrm{mg} \mathrm{kg}^{-1}$ de cobre e cultivado em casa de vegetação com nove plantas: Canavalia ensiformis, Cajanus cajan, Dolichos lablad, Mucuna cinereum, Mucuna aterrima, Crotalaria juncea, Crotalaria spectabilis, Pennisetum glaucum e Paspalum notatum. Aos 90 dias após a semeadura as plantas foram avaliadas quanto à produção de massa seca de parte aérea e raízes, teores de Cu, $N$, $P, K, C a, Z n$, e Fe na parte aérea e de Cu nas raizes. As altas concentrações de Cu no solo reduziram a absorção de fósforo pelas plantas. $O$ feijão-de-porco apresenta potencial para a fitoextração, pois apresentou translocação de altas concentrações de cobre para os tecidos aéreos, enquanto que as mucunas preta e cinza são indicadas para programas de fitoestabilização de cobre, pois acumularam elevada concentração de cobre no sistema radicular.

Palavras-chave: metal pesado, poluição do solo, fitorremediação, fitoestabilização, fitoextração.

\section{INTRODUCTION}

The soil copper contamination is a problem that occurs in several countries (MIRMONSEF et al., 2017). In Brazil, the principal areas susceptible to copper contamination are the wastes disposed from mining, swine breeding and vineyards. Although, the areas affected by mining are comparatively small, they showed high contamination levels (PERLATTI et al., 2015). On the contrary, large areas exhibiting less copper contamination levels are observed where large quantities of liquid swine manure are frequently disposed, as food rations are high in copper (MALLMANN et al., 2014). The same is true 
for vineyards due to the repeated addition of cupric fungicide (GIROTTO et al., 2016).

In southern Brazil, ANDREAZZA et al. (2013) reported high $\mathrm{Cu}$ contamination levels (576 mg kg-1 extracted by $\mathrm{HC} 10.1 \mathrm{~mol} \mathrm{~L}^{-1}$ ) in the mining waste disposal regions of the Camaquã River basin. In their study, Tiecher et al. (2013) in the agricultural areas used for frequent liquid swine manure disposal quantified $29 \mathrm{mg} \mathrm{kg}^{-1}$ (Cu-EDTA) in the surface sandy soil layer. According to CASALI et al. (2008) copper concentration as high as $506 \mathrm{mg}$ $\mathrm{kg}^{-1}$ (extracted by $30 \% \mathrm{H}_{2} \mathrm{O}_{2}$ and $\mathrm{HF}+\mathrm{HClO}_{4}$ ), was reported at 0 to $20 \mathrm{~cm}$ depth in the Humic Cambisol supporting the vineyards.

Copper is an indispensable micronutrient for all living organisms as it plays a crucial role in several physiological processes including respiration, photosynthesis and nitrogen fixation. (FEKIACOVA et al., 2015, RUSCINITTI et al., 2017). However, when copper is present in high concentrations in animals it can cause enzyme inactivation, liver diseases, muscle pain, nervous alterations, vomiting and, in severe instances of overexposure, even death (MAHER, 2018).

In plants, high copper levels induce decreased growth, chlorosis and foliar necrosis (ANJUM et al., 2015). Metal toxicity is evident in the reduced root length, biomass and production of photosynthetic pigments, as well as a decline in the absorption of essential nutrients by the plants (DE MARCO et al., 2017; XU et al., 2017). According to CAETANO et al., (2016), 28mg kg-1 (USEPA method) are damaging to the development of plants and other soil organisms. Decline or impairment of plant development potentiates particle transport through surface runoff and copper transference to the surface waters. Besides, the lack of an active root system permits greater percolation through the soil profile, and copper cycling in the soil-plant system is nil. Copper contamination of soil and water exposes several living organisms to these metals, with possibility of intoxication at different links in the trophic chain and impeding vital ecosystem services (CORNU et al., 2017; RUSCITTI et al., 2017).

Some plants can grow in soils containing high heavy metal concentrations. Phytoremediation is an effective alternate technique to treat such soils. This method involves employing plants to stabilize or remove an environmental contaminant (MAHAR et al., 2016). This environmental biotechnology is relatively new and present cost effective and well accepted as a natural pollution control method. Well recognized phytoremediation processes include phytodegradation, phytovolatilization, phytostimulation, rhizodegradation, phytostabilization and phytoextraction (ALI et al., 2013). While phytoremediation is a means of minimizing the migration of the heavy metal through the soil, phytostabilization is useful with plants that immobilize and/or accumulate large quantities of copper in the root system, reducing its translocation to the aerial plant organs (SANTIBÁÑEZ et al., 2008). If the aim is to eliminate the copper from the contaminated soil, phytoextraction can be employed with plants which store large quantities of copper in the aerial tissues (KUMAR et al., 1995).

In spite of the serious environmental problem caused by copper contamination and the enormous plant diversity in Brazil, only a few studies have investigated the behavior of the cover plants in terms of accumulation of dry mass, absorption and translocation of the copper to their root and aerial tissues, even though they have been used for many years and practically throughout the national territory, for the most diverse purposes. This information is essential so that suitable plants can be selected for phytoremediation programs aiming to controll the high copper pollution present in several areas of the country. In this way, the objective of this research was to explore the behavior of nine summer cover crops regarding growth, absorption and translocation of copper in soils with contamination levels exceeding the Value of Prevention, with a view to select plants for phytoremediation programs.

\section{MATERIALS AND METHODS}

\section{Soil}

A Humic Cambisol without history of contamination was collected from a depth of 0 to $20 \mathrm{~cm}$ in EMBRAPA Uva e Vinho (Bento Gonçalves/ RS, 2909"44”S; 51'31'50”W). Soil analysis presented the following values: clay (densimeter) $500 \mathrm{~g} \mathrm{~kg}^{-1}$; organic matter (Walkley-Black) $35 \mathrm{~g} \mathrm{~kg}^{-}$ 1; $\mathrm{pH}$ (water 1: 1) 4.0; P (Mehlich-1) 3.7mg dm${ }^{-3}$; K (Mehlich-1) 92.0mg dm-3 $\mathrm{Cu}$ (Mehlich-1) $2.9 \mathrm{mg} \mathrm{dm}^{-}$ 3; Zn (Mehlich-1) 3.3 $\mathrm{mg} \mathrm{dm}^{-3}$; base saturation 9.0\%; and aluminum saturation $60.5 \%$.

After drying and sieving the soil, $\mathrm{pH}$ was corrected to 5.5 by adding calcium hydroxide and magnesium oxide in the molar ratio of $2: 1$ (of $\mathrm{Ca}$ and $\mathrm{Mg}$ ). Soil was incubated for 60 days with $80 \%$ moisture of the field capacity. After, phosphorus and potassium were added so that their contents were elevated to a high level (CQFS RS/SC, 2016). Soil was contaminated with increasing doses of copper $(0$, 
$100,200,400,500$ and $600 \mathrm{mg} \mathrm{kg}^{-1}$ of soil) using an aqueous solution composed of $66.66 \%(\mathrm{~m} / \mathrm{v})$ copper chloride and $33.34 \%(\mathrm{~m} / \mathrm{v})$ copper sulfate, to achieve concentrations above $60 \mathrm{mg} \mathrm{kg}^{-1}$, the Prevention Value according to CETESB (2016). Before the planting, copper levels present in the soil were determined by three different methods: Melich-1 (MELICH, 1953), 0.1 $\mathrm{mol} \mathrm{L}^{-1} \mathrm{HCl}$ (TEDESCO et al., 1995) and $0.01 \mathrm{~mol} \mathrm{~L}^{-1} \mathrm{Na}_{2}$-EDTA $1.0 \mathrm{~mol} \mathrm{~L}^{-1}$ ammonium acetate (CHAIGNON et al., 2009). The Mehlich-1 method was performed by adding $10 \mathrm{~mL}$ of the extractive solution $\left(8.10 \mathrm{~mL}\right.$ of $\mathrm{HCl}$ P.A $+1.40 \mathrm{~mL}^{\circ} \mathrm{H}_{2} \mathrm{SO}_{4}$ P.A) to $1 \mathrm{~g}$ of soil and followed by stirring for $5 \mathrm{~min}$. It was centrifuged 18 hours later, at 7,500g. To determine the copper using $\mathrm{HCl}, 10 \mathrm{~mL}$ of the $0.1 \mathrm{~mol} \mathrm{~L}^{-1} \mathrm{HCl}$ solution was added in $40 \mathrm{~g}$ of soil, and stirred for $30 \mathrm{~min}$. After $24 \mathrm{~h}, 10 \mathrm{~mL}$ of this supernatant was drawn out. To determine the $\mathrm{Cu}$ level using $\mathrm{Na}_{2}$-EDTA/ ammonium acetate, $1 \mathrm{~mL}$ of the solution of $\mathrm{Na}_{2}$-EDTA $0.01 \mathrm{~mol} \mathrm{~L}^{-1} /$ ammonium acetate $1.0 \mathrm{~mol} \mathrm{~L}^{-1}$ was added at $\mathrm{pH} 7.0$ to $0.25 \mathrm{~g}$ of soil. The mixture was stirred for two hours and centrifuged for $3 \mathrm{~min}$ at $15,000 \mathrm{~g}$. Supernatants from all the soil extracts the copper content was ascertained in an atomic absorption spectrometer ( $882 \mathrm{~nm}$ wave length, $0.057 \mathrm{mg} \mathrm{L}^{-1}$ of $\mathrm{Cu}$ sensitivity, flame air/acetylene).

\section{Experimental design}

The study was divided in two experiments. The first one involved 40 treatments, in a $4 \times 10$ factorial design, using four copper doses $(0,100,200$ and $400 \mathrm{mg}$ of copper per $\mathrm{kg}$ of soil) and nine plant genotypes, plus control soil (without cultivation). The completely randomized design was adopted with three replications, to give a total of 120 experimental units. The nine genotypes evaluated included: Canavalia ensiformis DC., Cajanus cajan L., Dolichos lablab L., Mucuna cinereum L., Mucuna aterrima L., Crotalaria juncea L., Crotalaria spectabilis Roth., Pennisetum glaucum L. and Paspalum notatum L. The Canavalia ensiformis, Mucuna cinereum and $M$. aterrima displayed the highest growths and were therefore, chosen for the second experiment.

The second experiment involved cultivation under doses of copper in the concentrations of $0,400,500$ and $600 \mathrm{mg} \mathrm{kg}^{-1}$ in the same soil and under the conditions identical to those of the first experiment. In the second experiment 12 treatments were distributed in a $4 \times 3$ factorial design, with four copper doses and three plant genotypes (Canavalia ensiformis, Mucuna cinereum and M. aterrima). The completely randomized design was adopted, with three replications, for a total of 36 experimental units.

\section{Plant cultivation}

$\mathrm{N}_{2}$-fixing bacteria recommended for each crop were inoculated into seeds of the leguminous plants. Grasses were provided nitrogen fertilization via ammonium nitrate at the time of sowing and during two other cover applications, based on the technical recommendations (CQFS RS/SC, 2016). The 5-L capacity plastic pots were filled with $4 \mathrm{~kg}$ of soil. Nine seeds from each plant genotype were sown in each vessel. Some plants have been removed eight days post germination, until only three plants remained per pot. Soil moisture was maintained at $80 \%$ of the field capacity by recording the daily pots weights and adding distilled water when required.

\section{Plant analysis}

Plants were harvested at 90 days post sowing, and the aerial parts were cut close to the soil level. Then the roots were manually cleaned to remove the soil and washed under water, $0.02 \mathrm{~mol} \mathrm{~L}^{-1}$ EDTA solution and distilled water, respectively. For the dry mass determination of shoots and roots were oven dried with forced air circulation at $65^{\circ} \mathrm{C}$ until constant mass was achieved. To determine the concentrations of copper, phosphorus, potassium, calcium, iron and zinc in the aerial and roots tissues plant tissues, nitricperchloric $\left(\mathrm{HNO}_{3}+\mathrm{HClO}_{4}\right)$ was added to digest the dry and crushed tissue samples. As it is risky to handle the perchloric acid in the laboratory, this solution was prepared under stringent safety measures (TEDESCO et al., 1995). The copper, calcium (after addition of $\mathrm{Sr}$ $0.3 \%$ in $0.2 \mathrm{M} \mathrm{HCl}$ ), iron and zinc concentrations were determined using an atomic absorption spectrometer (GBC, 932 AA, Australia). The N content in the shoot was determined by the Kjeldahl-1 method post sulfur digestion (BREMNER; MULVANEY, 1982). The K was determined using the flame photometer (DM-62, DIGIMED, Brazil) while the $\mathrm{P}$ was assessed through colorimetry, according to MURPHY and RILEY (1962).

\section{Statistical analysis}

The bioaccumulation factor (BF) was calculated by dividing the copper concentration in the root and the copper levels present in the soil (Mehlich-1) (LAI et al., 2010). The Translocation Index (Ti) was determined by dividing the copper concentration in the shoot by that presented in the root system.

The data on the dry mass and absorption of the chemical elements were submitted to the analysis of variance. Averages were compared using the ScottKnott test with $5 \%$ probability of error, employing the SISVAR 5.6 program. Regression equations were confirmed by the best fit with the Table Curve 
2D for Windows v. 5.01 (SYSTAT Software Inc). Pearson's correlations for nutrient levels and dry mass production were also estimated using STATISTICA 7 (Stat Soft, Inc., USA).

\section{RESULTS AND DISCUSSION}

\section{Copper content in soil}

The addition of copper to the soil in doses of $0,100,200,400,500$ and $600 \mathrm{mg} \mathrm{kg}^{-1}$ in the form of an aqueous solution of copper chloride $(66.66 \%)$ and copper sulfate $(33.34 \%)$ resulted the available concentrations of $0.94 ; 35.79 ; 58.60 ; 166.14 ; 198.69$ and $232.11 \mathrm{mg} \mathrm{kg}^{-1}$ of $\mathrm{Cu}$ extracted by Melich-1; concentrations of $1.16 ; 47.95 ; 72.29 ; 218.83$; 260.02 and $304.67 \mathrm{mg} \mathrm{kg}^{-1} \mathrm{Cu}$ were extracted with $0.1 \mathrm{~mol} \mathrm{~L}^{-1} \mathrm{HCl}$; and concentrations of 12.14 ; 95.56 ; $136.03 ; 324.23 ; 386.46$ and $452.28 \mathrm{mg} \mathrm{kg}^{-1}$ were extracted with $\mathrm{Na}_{2}$-EDTA $0.01 \mathrm{~mol} \mathrm{~L}^{-1} / \mathrm{ammonium}$ acetate $1.0 \mathrm{~mol} \mathrm{~L}^{-1}$. In all the three extractions, high correlation values were noted between the copper available in the soil and the accumulated copper in the aerial parts of the $C$. ensiformis, $M$. aterrima and M. cinereum (Figure 1).

Addition of increasing doses of $\mathrm{Cu}$ resulted in high levels of available heavy metal in the soil,

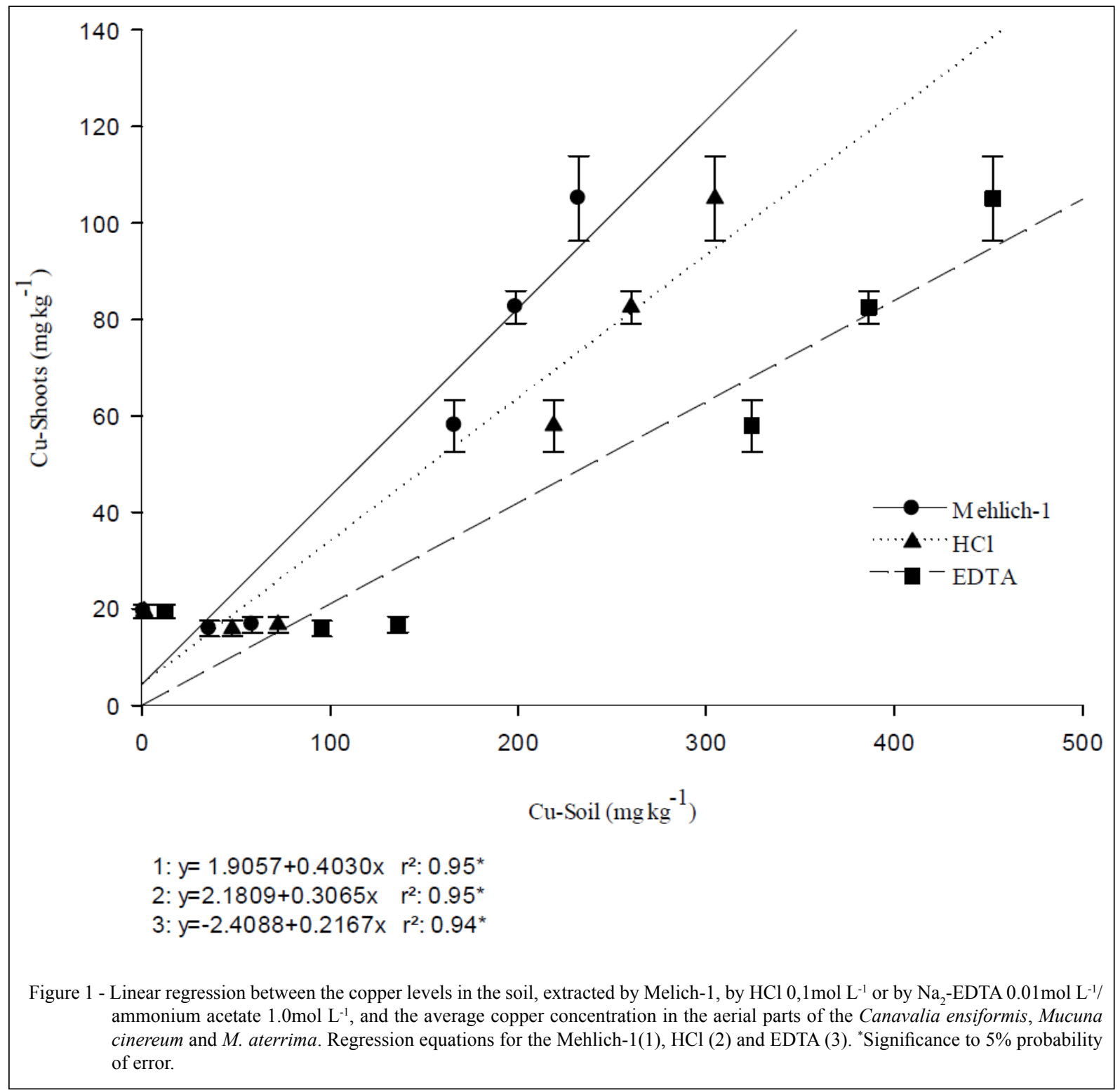

Ciência Rural, v.48, n.12, 2018. 
similar to those observed in several contaminated areas of Brazil (BRUNETTO et al., 2013; ANDREAZZA et al., 2013). According to PERLATTI et al., (2015) the soil available metal content are determined by extractors solutions that showed a high correlation with the heavy metal concentrations in the plant tissues. Under the experimental conditions of this study, the Mehlich-1 extractor revealed a higher correlation with the $\mathrm{Cu}$ levels in the plants.

\section{Experiment 1}

The dry matter yield of the aerial plant parts and root system of the nine cover crops was observed to decrease as the copper doses in the soil increased (Figure 2); however, different degrees of tolerance to the heavy metal were evident. The plants P. glaucum, C. cajan, P. notatum, C. juncea, $C$. spectabilis and D. lablab showed low tolerance for copper and were unsuitable for cultivation in

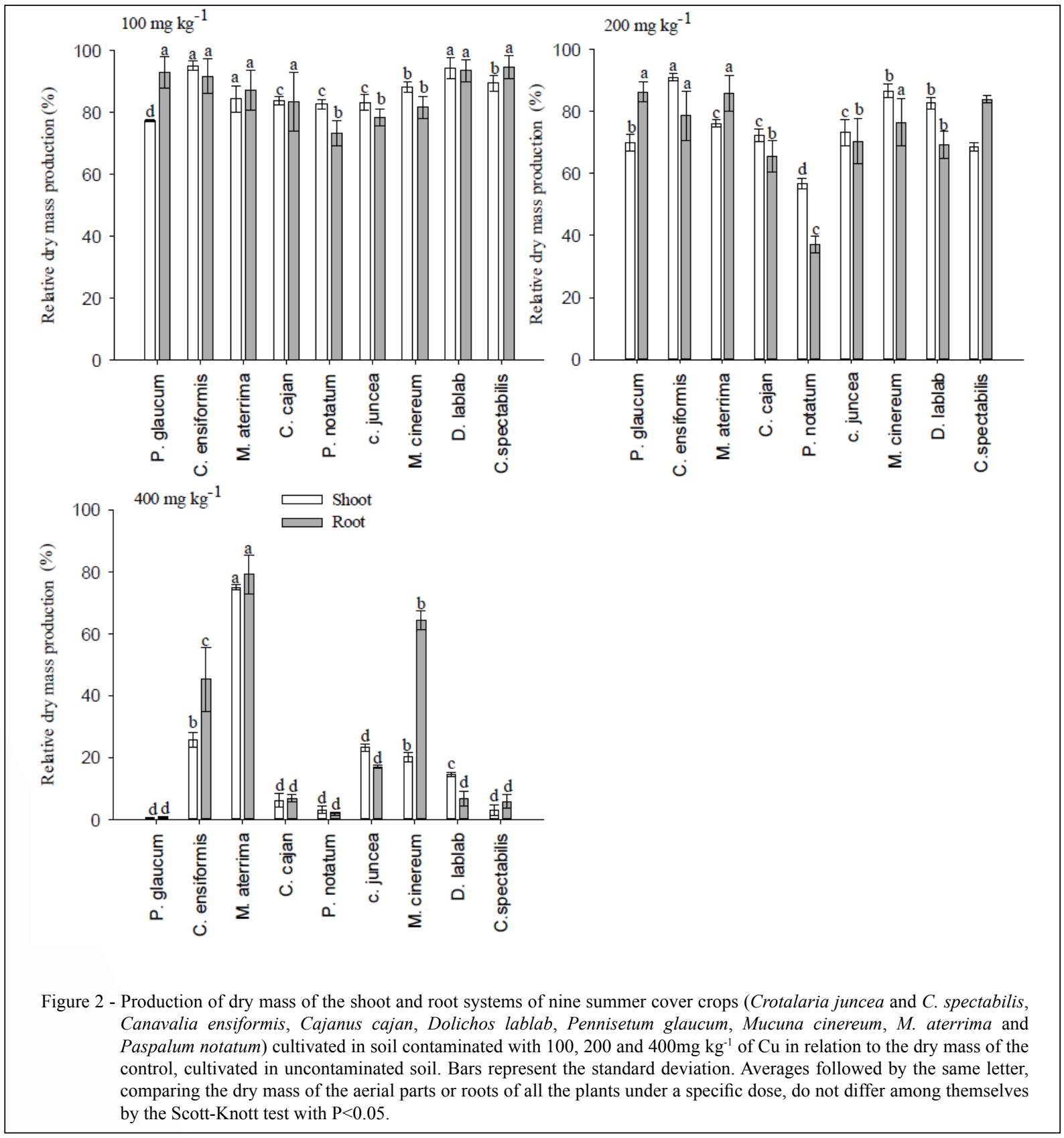

Ciência Rural, v.48, n.12, 2018. 
copper-contaminated soils. All plants revealed significantly decreased growth in response to copper doses above $100 \mathrm{mg} \mathrm{kg}^{-1}$ in the soil. Copper induces many physiological damages like stomatal closure, protein complex denaturation, and phaeophyte modifications, besides the formation of $\mathrm{Cu}$-chlorophyll complexes, and inhibition of the photosystem II reaction center, causing poor plant development (BAZIHIZINA et al., 2015).

C. ensiformis was identified as having the highest copper tolerance at the dose of $200 \mathrm{mg}$ $\mathrm{kg}^{-1}$ (Figure 2). These plants also exhibited the least decrease in the yield of the dry matter of shoots and roots when compared with the control. At the highest dose added, the $C$. ensiformis produced the second largest quantity of shoot dry mass. $M$. aterrima was the most copper-tolerant plant at the $400 \mathrm{mg} \mathrm{kg}^{-1}$ dose (Figure 2). It is emphasized that dry matter of the shoot and roots produced were only $30 \%$ and $27 \%$ less, respectively, than that of the control. The $M$. cinereum was distinctive for its high quantity of dry mass of the roots at the $400 \mathrm{mg} \mathrm{kg}^{-1}$ dose (Figure 2). $C$. ensiformis, $M$. aterrima and $M$. cinereum clearly emerged as the plants with the highest tolerance for the copper levels tested and were therefore, selected for experiment 2.

\section{Experiment 2}

The three plants selected showed a dramatic drop in development in response to the increasing doses of copper (Figure 3). A strong negative correlation was observed between the dry mass and $\mathrm{Cu}$ content in the shoot and roots of all three plants $\left(M\right.$. cinereum: $\mathrm{r}_{\text {Cu shoot }}-0.98, \mathrm{r}_{\text {Cu root }}-0.96, M$. aterrima: $\mathrm{r}_{\mathrm{Cu} \text { shoot }}-0.91, \mathrm{r}_{\mathrm{Cu} \text { root }}-0.89 ;$ C. ensiformis: $\mathrm{r}_{\text {Cu shoot }}-0.90, \mathrm{r}_{\text {Cu root }}:-0.95$, all having $\mathrm{P}<0.001$ ). However, it was remarkable that for the three doses evaluated, the $C$. ensiformis displayed the highest shoot dry mass production. Again the M. aterrima was highlighted by root system growth at copper doses of 400 and $500 \mathrm{mg} \mathrm{kg}^{-1}$, very similar to the control.

The accumulation of copper in the tissues increased according to the dose of copper added to the soil (Table 1). C. ensiformis showed the highest copper levels in the shoot, about 60, 30 and 55\% more than the average of the Mucuna spp., at the 400, 500 and $600 \mathrm{mg} \mathrm{kg}^{-1}$ doses of $\mathrm{Cu}$, respectively. The
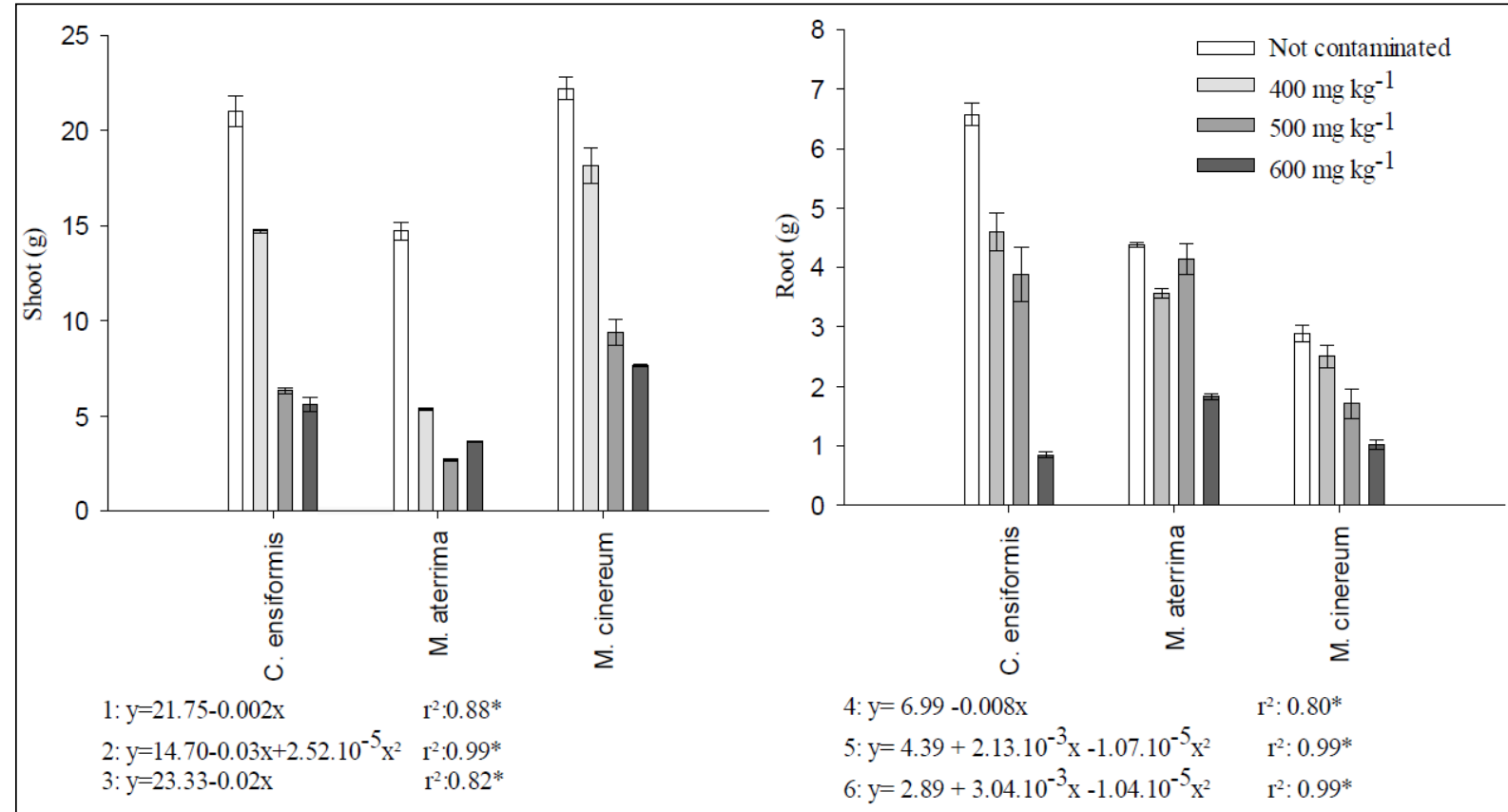

Figure 3 - Dry mass of the aerial parts and roots produced by the Canavalia ensiformis, Mucuna aterrima and M. cinereumin soils uncontaminated and contaminated with copper at 400, 500 and $600 \mathrm{mg} \mathrm{kg}^{-1}$. Bars represent the standard deviation. Regression equations for the M. cinereum (1 and 4), M. aterrima (2 and 5) and C. ensiformis ( 3 and 6), where $\mathrm{x}$ is the copper dose in the soil and $y$ the dry mass production of the plant, with the coefficient of determination significant $\left(^{*}\right)$ to $5 \%$ probability of error. 
Table 1 - Copper levels in the shoot and root, bioaccumulation factor and translocation index of the summer cover crops Mucuna cinereum, M.aterrima and Canavalia ensiformis, after growth in uncontaminated and contaminated soils with 400,500 and $600 \mathrm{mg} \mathrm{kg}^{-1}$ of copper. Averages followed by the same letter, upper case comparing plants in one dose, and lower case comparing only one plant at different doses, did not differ among themselves by the Scott-Knott test with $\mathrm{P}<0.05$.

\begin{tabular}{|c|c|c|c|c|c|c|c|c|}
\hline \multirow[t]{2}{*}{ Plants } & \multicolumn{4}{|c|}{----------- $\mathrm{Cu}$ content in the shoot $\left(\mathrm{mg} \mathrm{Cu} \mathrm{kg}^{-1}\right)$----------- } & \multicolumn{4}{|c|}{ 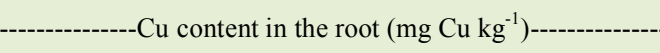 } \\
\hline & 0 & 400 & 500 & 600 & 0 & 400 & 500 & 600 \\
\hline M. cinereum & $14.9 \mathrm{Ac}$ & $39.9 \mathrm{Cb}$ & $74.3 \mathrm{Ba}$ & $84.6 \mathrm{Ba}$ & 40.6 Ad & $813.1 \mathrm{Ac}$ & $1421.5 \mathrm{Ab}$ & 1866.4 Aa \\
\hline M. aterrima & $22.1 \mathrm{Ad}$ & $57.7 \mathrm{Bc}$ & $80.1 \mathrm{Bb}$ & $93.1 \mathrm{Ba}$ & $51.4 \mathrm{Ad}$ & $687.1 \mathrm{Bc}$ & $950.8 \mathrm{Bb}$ & $1356.9 \mathrm{Ba}$ \\
\hline \multirow[t]{2}{*}{ C. ensiformis } & $21.7 \mathrm{Ad}$ & $76.2 \mathrm{Ac}$ & $93.3 \mathrm{Ab}$ & $137.7 \mathrm{Aa}$ & $22.1 \mathrm{Ac}$ & $264.9 \mathrm{Cd}$ & $311.9 \mathrm{Cb}$ & $473.2 \mathrm{Ca}$ \\
\hline & \multicolumn{4}{|c|}{-----------------Bioaccumulation Factor (BF)---------------- } & \multicolumn{4}{|c|}{-------------------Translocation Index (Ti)------------------- } \\
\hline M. cinereum & 43.18 & 4.89 & 7.15 & 8.04 & 0.36 & 0.04 & 0.05 & 0.04 \\
\hline M. aterrima & 54.68 & 4.13 & 4.78 & 5.84 & 0.43 & 0.08 & 0.08 & 0.06 \\
\hline C. ensiformis & 23.54 & 0.45 & 1.56 & 2.03 & 0.98 & 0.28 & 0.29 & 0.29 \\
\hline
\end{tabular}

BF: Estimated by the division between the copper level in the root $\left(\mathrm{mg} \mathrm{kg}^{-1}\right)$ and the copper concentration in the soil ( $\left.\mathrm{mg} \mathrm{kg}^{-1}\right)$, evaluated by the Mehlich-1 extractor. Ti: Estimated by the division between the copper level in the aerial parts $\left(\mathrm{mg} \mathrm{kg}^{-1)}\right.$ and the copper concentration in the plant roots $\left(\mathrm{mg} \mathrm{kg}^{-1}\right)$.

Mucuna spp. root systems could accumulate much higher copper levels compared with that of the $C$. ensiformis, for all the doses tested. This is confirmed by the Mucuna spp. bioaccumulation factor, which showed on average, ten times higher value at the $400 \mathrm{mg} \mathrm{kg}^{-1}$ dose and a three times higher value at the $600 \mathrm{mg} \mathrm{kg}^{-1}$ dose when compared to the $C$. ensiformis (Table 1 ). The $M$. cinereum notably absorbed $18 \%$, $50 \%$ and $38 \%$ more copper, respectively, via the root system than did the $M$. aterrima, at the doses of 400 , 500 and $600 \mathrm{mg} \mathrm{kg}^{-1}$ of $\mathrm{Cu}$.

While the Mucuna spp. absorbed large quantities of copper through the root systems, they translocated much less to the shoot. The C. ensiformis; however, takes up less copper via the root system, but translocate more amounts to the shoot system. The translocation index (Table 1), confirmed this differential behavior where the average values for the C. ensiformis are five times higher than those seen for the Mucuna spp. in the copper-contaminated soil.

On exposure to high copper levels in the soil, the $C$. ensiformis, $M$. aterrima and $M$. cinereum exhibited less growth decrease when compared with the other plants. All three are leguminous. According to HAO et al., (2014), plants that can form symbiotic associations with $\mathrm{N}_{2}$-fixing bacteria increase their ability to tolerate various stresses and grow better in metal-contaminated soils.

Independently of the $\mathrm{Cu}$ dose added to the soil, the $C$. ensiformis exhibited an increase in the shoot production, showing statistical difference from the other plants evaluated. Besides, in relation to the
Mucuna spp., the $C$. ensiformis takes up less copper via the root system, but translocate greater amounts to the shoot. According to PUGA et al., (2015) C. ensiformis has higher transfer rate for several metals in comparison to the $M$. aterrima, and is; therefore, being considered as plant with potential for phytoextraction programs in copper-contaminated soils.

The $C$. ensiformis can accumulate high levels of copper in the aerial parts and still produce high biomass, which can likely be linked to the production of phytochelatins in the foliar tissues, and which in turn lowers the concentration of the free metal in the cytosol, restricting its solubility and reactivity (OLIVA et al., 2010). Besides, some physiological mechanisms may help to minimize the toxic reactions of the metal in the plant, such as the differential output of the antioxidative and carotenoid enzymes, metal complexation within the cell compartments (like the vacuole), increase in the yield of organic acids to complex the metal, and high expression of metal-carrying proteins.

The increase in the copper levels in the soil induced a decline in the phosphorus absorption in all three plants (Table 2). A strong negative correlation was observed between the $\mathrm{P}$ and $\mathrm{Cu}$ absorption, in the root as well as the shoot $\left(M\right.$. cinereum: $\mathrm{r}_{\mathrm{Cu} \text { shoot }}$ $-0.91, \mathrm{r}_{\text {Cu root }}-0.93$, M. aterrima: $\mathrm{r}_{\text {Cu shoot }}-0.89, \mathrm{r}_{\text {Cu root }}$ -0.88 ; C. ensiformis: $\mathrm{r}_{\mathrm{Cu} \text { shoot }}-0.93, \mathrm{r}_{\mathrm{Cu} \text { root }}:-0.97$, all with $\mathrm{P}<0.001)$. The presence of excess copper in the roots reduces the branching, thickening and causes lower root development, which in turn decreases the phosphorus absorption (YRUELA et al., 2005). 
Table 2 - Nutrient levels in the shoot of the Mucuna cinereum, M. aterrima and Canavalia ensiformis cultivated in uncontaminated and contaminated soils with400, 500 and $600 \mathrm{mg} \mathrm{kg}^{-1}$ copper. Averages followed by the same letter, upper case comparing plants in one dose, and lower case comparing only one plant at different doses, did not differ among themselves by the Scott-Knott test with $\mathrm{P}<0.05$.

\begin{tabular}{|c|c|c|c|c|c|c|}
\hline Plants & $\mathrm{N}\left(\mathrm{g} \mathrm{kg}^{-1}\right)$ & $P\left(\mathrm{~g} \mathrm{~kg}^{-1}\right)$ & $\left.\mathrm{K} \mathrm{g} \mathrm{kg}^{-1}\right)$ & $\mathrm{Ca}\left(\mathrm{g} \mathrm{kg}^{-1}\right)$ & $\mathrm{Fe}\left(\mathrm{mg} \mathrm{kg}^{-1}\right)$ & $\mathrm{Zn}\left(\mathrm{mg} \mathrm{kg}^{-1}\right)$ \\
\hline \multicolumn{7}{|c|}{$\begin{array}{l}- \\
-\end{array}$} \\
\hline M. cinereum & $1.64 \mathrm{Ab}$ & $1.12 \mathrm{Aa}$ & $6.93 \mathrm{Aa}$ & $1.06 \mathrm{Aa}$ & $710.28 \mathrm{Ab}$ & $67.18 \mathrm{Ba}$ \\
\hline M. aterrima & $1.32 \mathrm{Bc}$ & $1.12 \mathrm{Aa}$ & $5.93 \mathrm{Ba}$ & $1.04 \mathrm{Bb}$ & $663.22 \mathrm{Ab}$ & $81.19 \mathrm{Ab}$ \\
\hline C. ensiformis & $1.12 \mathrm{Cc}$ & $1.08 \mathrm{Aa}$ & $4.60 \mathrm{Ca}$ & $0.98 \mathrm{Cb}$ & $706.58 \mathrm{Ac}$ & $94.08 \mathrm{Aa}$ \\
\hline \multicolumn{7}{|c|}{ - } \\
\hline M. cinereum & $1.52 \mathrm{Bb}$ & $0.66 \mathrm{Bb}$ & $6.48 \mathrm{Aa}$ & $1.05 \mathrm{Aa}$ & $501.12 \mathrm{Bc}$ & $66.85 \mathrm{Ba}$ \\
\hline M. aterrima & $1.78 \mathrm{Aa}$ & $031 \mathrm{Cb}$ & $3.68 \mathrm{Cd}$ & $1.07 \mathrm{Aa}$ & $476.27 \mathrm{Bc}$ & $76.52 \mathrm{Bb}$ \\
\hline C. ensiformis & $1.38 \mathrm{Bb}$ & $0.94 \mathrm{Ab}$ & $4.47 \mathrm{Ba}$ & $1.03 \mathrm{Bb}$ & $1106.78 \mathrm{Aa}$ & $93.11 \mathrm{Aa}$ \\
\hline \multicolumn{7}{|c|}{ } \\
\hline M. cinereum & $1.86 \mathrm{Aa}$ & $0.56 \mathrm{Bc}$ & $6.72 \mathrm{Aa}$ & $1.06 \mathrm{Aa}$ & $840.11 \mathrm{Aa}$ & $72.17 \mathrm{Ca}$ \\
\hline M. aterrima & $1.88 \mathrm{Aa}$ & $0.27 \mathrm{Cb}$ & $4.30 \mathrm{Bb}$ & $1.05 \mathrm{Aa}$ & $609.03 \mathrm{Bb}$ & $87.80 \mathrm{Bb}$ \\
\hline C. ensiformis & $1.83 \mathrm{Aa}$ & $0.77 \mathrm{Ac}$ & $3.62 \mathrm{Cc}$ & $1.03 \mathrm{Ba}$ & $885.42 \mathrm{Ab}$ & $103.42 \mathrm{Aa}$ \\
\hline \multicolumn{7}{|c|}{-------------------------------------------------------------------------600mg kg-1 } \\
\hline M. cinereum & $1.46 \mathrm{Bb}$ & $0.46 \mathrm{Bd}$ & $7.04 \mathrm{Aa}$ & $1.01 \mathrm{Bb}$ & $671.52 \mathrm{Cb}$ & $79.58 \mathrm{Ba}$ \\
\hline M. aterrima & $1.66 \mathrm{Ab}$ & $0.26 \mathrm{Cb}$ & $4.14 \mathrm{Cc}$ & $1.05 \mathrm{Ab}$ & $875.25 \mathrm{Ba}$ & $101.49 \mathrm{Aa}$ \\
\hline C. ensiformis & $1.50 \mathrm{Bb}$ & $0.61 \mathrm{Ad}$ & $4.30 \mathrm{Bb}$ & $1.00 \mathrm{Bb}$ & $1070.84 \mathrm{Aa}$ & 104.77 Aa \\
\hline
\end{tabular}

ADHIKARI et al., (2016) reported less root growth in the plants exposed to high copper doses. Electron microscopy revealed that the copper was stored as aggregates, in the vascular systems, avoiding nutrients and water absorption.

For most cases, the $C$. ensiformis absorbed remarkably higher quantities of phosphorus, iron and zinc when compared with the Mucuna spp. (Table 2). The other nutrients showed little or no tendency to increase or decrease the absorption in response to the increase of copper doses in the soil.

From the research of TIECHER et al. (2016) it becomes clear that certain plants can absorb zinc and iron rather than copper because these elements possess several ionic carriers in common as they have similar chemical properties (ionic radius, bivalence, etc.). Likewise, plants with higher capacity to take up phosphorus, maintain a better nutritional status. The phosphorus facilitates the complexation of heavy metals via the phosphate-metal bonds inside the cells (FERREIRA et al., 2015).

The root system of the Mucuna spp. exhibited extraordinary growth capacity despite very high doses of copper present in the soil. According to FAGERIA et al. (2014) the $M$. aterrima and $M$. cinereum produced a higher root dry mass in a copper-contaminated soil when compared with the other species, including the $C$. ensiformis. Besides, the Mucuna spp. showed most of the heavy metal concentrated in their roots, particularly the $M$. cinereum. The root system of some plant species possess mechanisms which can decrease the $\mathrm{Cu}$ translocation to the shoot, like chelation to the organic acids and/or other nutrients and metal compartmentalization within the vacuoles (RODRIGUES et al., 2016). PUGA et al. (2015) reported that the M. aterrima has the ability to accumulate the calcium oxalate crystals in their vascular bundles, which protect the plant against excess of metals in the tissue. Therefore, these plants are suited for phytostabilization of the copper-contaminated soils as they accumulate large quantities of the heavy metal in the root system and yield a high dry mass of the root.

The $C$. ensiformis, $M$. aterrima and M. cinereum, all of which are legumes, showed the highest tolerance to the presence of excess copper levels. However, each of these plants shows different responses to the excess copper present in the soil. C. ensiformis accumulates low quantities of copper in the roots, but translocates high amounts of $\mathrm{Cu}$ to the aerial tissues and yet is able to produce a high aerial tissue dry mass. Thus, when the goal of phytoremediation is the copper phytoextraction, the $C$. ensiformis emerges as an alternative. However, the Mucuna spp. yield 
a high dry mass of the roots and accumulate great quantities of $\mathrm{Cu}$ in the root system, but translocate low amounts of copper to the aerial tissues. Thus, the Mucuna spp. appear to be better suited for copper phytostabilization. Agricultural areas may be more amenable to phytoextraction, as soil management involving fertilization, $\mathrm{pH}$ correction (AGBENIN, OLOJO, 2004; TIECHER ET AL., 2013; SANTANA et al., 2018) and soil preparation (CASTRO et al., 1992; MOREIRA et al., 2016) can make the metal available once more. On the contrary, in soils with very high contamination levels, plants are not easy to use as phytoextraction, and phytostabilization becomes significant as an alternative to minimize the environmental mobility of the metal.

\section{CONCLUSION}

C. ensiformis produces high quantities of dry matter and accumulate large amounts of copper in the aerial tissues, revealing their potential for use in the copper phytoextraction programs.

$M$. aterrima and $M$. cinereum produce high amounts of dry mass and accumulated high concentrations of copper in the root system, demonstrating their potential for use in the copper phytostabilization programs.

In soils contaminated with copper concentrations above the Reference Value, the absorption of the other nutrients by the plants also change; however, this effect is dependent on the genotype and the nutrient involved.

\section{DECLARATION OF CONFLICTING INTERESTS}

The authors have no conflict of interest to declare The founding sponsors had no role in the design of the study; in the collection, analyses, or interpretation of data; in the writing of the manuscript, and in the decision to publish the results.

\section{ACKNOWLEDGEMENTS}

This study was financed in part by the Coordenação de Aperfeiçoamento de Pessoal de Nível Superior - Brasil (CAPES) - Finance Code 001 and Conselho Nacional de Desenvolvimento Científico e Tecnológico (CNPq/Brazil).

\section{AUTHORS' CONTRIBUTIONS}

All authors contributed equally for the conception and writing of the manuscript. All authors critically revised the manuscript and approved of the final version.

\section{REFERENCES}

ADHIKARI, T. et al. Growth and enzymatic activity of maize (Zea mays L.) plant: Solution culture test for copper dioxide nanoparticles. Journal of Plant Nutrition, v. 39, n. 1, p. 99-115, 2016. Available from: <https://www.tandfonline.com/doi/abs/10 .1080/01904167.2015.1044012>. Accessed: Nov. 16, 2017. doi: 10.1080/01904167.2015.1044012.

AGBENIN, J. O.; OLOJO, L. A. Competitive adsorption of copper and zinc by a Bt horizon of a savanna Alfisol as affected by $\mathrm{pH}$ and selective removal of hydrous oxides and organic matter. Geoderma, v. 119, p. 85-95, 2004. Available from: <https://www. sciencedirect.com/science/article/pii/S0016706103002428>. Accessed: DeC. 12, 2017. doi: 10.1016/S0016-7061(03)00242-8.

ALI, H. et al. Phytoremediation of heavy metalsconcepts and applications. Chemosphere, v. 91, p.869881, 2013. Available from: <https://www.ncbi.nlm.nih.gov/ pubmed/23466085>. Accessed: Jan. 05, 2018. doi: 10.1016/j. chemosphere.2013.01.075.

ANDREAZZA, R. et al. Copper phytoextraction and phytostabilization by Brachiaria decumbens Stapf. in vineyard soils and a copper mining waste. Open Journal of Soil Science, v.3, p.273-282, 2013. Available from: <https://ainfo.cnptia. embrapa.br/digital/bitstream/item/91488/1/copper.pdf $>$. Accessed: Jan. 05, 2018. doi: 10.4236/ojss.2013.36032.

BAZIHIZINA, N. et al. Photosynthesizing on metal excess: Copper differentlyinducedchangesinvariousphotosyntheticparametersincopper tolerant and sensitive Silene paradoxa L. populations. Plant Science, v. 232, p. 67-76, 2015. Available from: <https://www.sciencedirect.com/ science/article/pii/S0168945214003021?via\%3Dihub>. Accessed: Jun. 13, 2017. doi: 10.1016/j.plantsci.2014.12.015.

BREMNER, J. M.; MULVANEY, C. S. Methods of soil analysis, Part 2. Chemical and microbiological properties. p. 595-624. 1982.

BRUNETTO, G. et al. Mobility of copper and zinc fractions in fungicide-amended vineyard sandy soils. Archives of Agronomy and Soil Science, v.60, p.609-624, 2014. Available from: <https:// www.tandfonline.com/doi/abs/10.1080/03650340.2013.82634>. Accessed: Jun. 13, 2017. doi: 10.1080/03650340.2013.826348.

CAETANO, A. L. et al. Copper toxicity in a natural reference soil: ecotoxicological data for the derivation of preliminary soil screening values. Ecotoxicology, v.25, p.163-177, 2016. Available from: <https://link.springer.com/article/10.1007\%2 Fs10646-015-1577-7>. Accessed: Jun. 10, 2017 doi: 10.1007/ s10646-015-1577-7.

CASALI, C. A. et al. Copper forms and desorption in soils under grapevine in the Serra Gaúcha of Rio Grande do Sul. Revista Brasileira de Ciência do Solo, v.32, p.1479-1487, 2008. Available from: <http://www.scielo.br/scielo.php?script=sci arttext\&pid=S0100-06832008000400012 >. Accessed: Mar. 17, 2017. doi: 10.1590/S0100-06832008000400012.

CASTRO, O. M. et al. Zinc, copper, manganese, andironcontent in two latosols from São Paulo State, Brazil, under conventionaland no-tillagecropping system. Bragantia, v. 51, p. 77-84. 1992. Available from: <http://www.scielo.br/scielo.php?script=sci_artte xt\&pid=S0006-87051992000100011>. Accessed: Mar. 16, 2017. doi: 10.1590/S0006-87051992000100011. 
CHAIGNON, V. et al. Copper availability and bioavailability are controlled by rhizosphere $\mathrm{pH}$ in rape grown in an acidic $\mathrm{Cu}-$ contaminated soil. Environmental Pollution, v.157, p.3363-3369, 2009. Available from: <https://linkinghub.elsevier.com/retrieve/ pii/S0269-7491(09)00327-3>. Accessed: Jan. 04, 2017. doi: 10.1016/j.envpol.2009.06.032

CORNU, J. Y. et al. Bioremediation of copper-contaminated soils by bacteria. World Journal of Microbiology Biotechnology, v. 33, 2017. Available from: <https://link.springer.com/article/10.100 7\%2Fs11274-016-2191-4>. Accessed: Jun. 13, 2018. doi: 10.1007/ s11274-016-2191-4

CQFS-RS/SC. Manual de Calagem e Adubação para os estados do Rio Grande do Sul e de Santa Catarina. 11. ed. Sociedade Brasileira de Ciência do Solo - Núcleo Regional Sul, 2016. 376p.

DE MARCO, R. et al. Organics Amendment and Eucalyptus grandis for Phytostabilization on Soil Contaminated with Copper. Floresta e Ambiente, v. 24, p. 1-9, 2017. Available from: <http://www. scielo.br/pdf/floram/v24/2179-8087-floram-2179-8087029315. pdf $>$. Accessed: Jun. 06, 2018. doi: 10.1590/2179-8087.029315.

FAGERIA, N. K.; BALIGAR, V. C. Evaluation of tropical legume cover crops for copper use efficiency. American Journal of Plant Sciences, v.5, p.1236-1247, 2014. Available from: $<\mathrm{https}$ ://ainfo. cnptia.embrapa.br/digital/bitstream/item/100601/1/nkfbaligar pdf > . Accessed: Nov. 02, 2017. doi: 10.4236/ajps.2014.59136.

FEKIACOVA, Z., S. et al. Tracing contamination sources in soils with $\mathrm{Cu}$ and $\mathrm{Zn}$ isotopic ratios. Science of The Total Environment, v. 517, p. 96-105, 2015. Available from: <https:// linkinghub.elsevier.com/retrieve/pii/S0048-9697(15)00189-8>. Accessed: Sept. 10, 2017. doi: 10.1016/j.scitotenv.2015.02.046.

FERREIRA, P. A. A. et al. Rhizophagus clarus and phosphate alter the physiological responses of Crotalaria juncea cultivated in soil with a high Cu level. Applied Soil Ecology, v.91, p.37-47, 2015. Available from: <https://www.sciencedirect.com/science/ article/pii/S0929139315000517 >. Accessed: Jun. 16, 2017. doi: 10.1016/j.apsoil.2015.02.008.

GIROTTO, E. et al. Biochemical changes in black oat (Avena strigosa Schreb) cultivated in vineyard soils contaminated with copper. Plant Physiology and Biochemistry, v. 103, p. 199-207, 2016. Available from: <https://www.sciencedirect.com/science/ article/abs/pii/S0981942816300559>. Accessed: Apr. 14, 2017. doi: 10.1016/j.plaphy.2016.02.030.

HAO, X. et al. Phytoremediation of heavy and transition metals aided by legume-rhizobia symbiosis. International Journal of Phytoremediation, v.16, p.179-202, 2014. Available from: $<$ https://www.ncbi.nlm.nih.gov/pubmed/24912209>. Accessed: Aug. 13, 2017. doi: 10.1080/15226514.2013.773273.

KUMAR, P. N. et al. Phytoextraction: the use of plants to remove heavy metals from soils. Environmental Science \& Technology, v.29, p. 1232-1238, 1995. Available from: <https://pubs.acs.org/ doi/pdf/10.1021/es00005a014>. Accessed: Sept. 12, 2017. doi: $10.1021 / \mathrm{es} 00005 \mathrm{a} 014$

LAI, H. Y. et al. Copper concentrations in grapevines and vineyard soils in central Taiwan. Journal of Soil Science and Plant Nutrition, v. 56, p. 601-606, 2010. Available from: <https://onlinelibrary. wiley.com/doi/epdf/10.1111/j.1747-0765.2010.00494.x>. Accessed: Aug. 12, 2018. doi: 10.1111/j.1747-0765.2010.00494.x.
MAHER, P. Potentiation of glutathione loss and nerve cell death by the transition metals iron and copper: Implications for age-related neurodegenerative diseases. Free Radical Biology and Medicine, v. 115, p. 92-104. 2018. Available from: <https://www.sciencedirect. com/science/article/pii/S0891584917312194?via\%3Dihub>. Accessed: Nov. 01, 2018. doi: 10.1016/j.freeradbiomed.2017.11.015.

MAHAR, A. et al. Challenges and opportunities in the phytoremediation of heavy metals contaminated soils: a review. Ecotoxicology and Environmental Safety, v. 126, p. 111-121. 2016. Available from: <https://www.sciencedirect.com/science/ article/pii/S0147651315302116>. Accessed: Nov. 02, 2018. doi: 10.1016/j.ecoenv.2015.12.023.

MALLMANN, F. J. K. et al. Soil tillage to reduce surface metal contamination-model development and simulations of zinc and copper concentration profiles in a pig slurry-amended soil. Agriculture, Ecosystems \& Environment, v. 196, p. 59-68. 2014. Available from: <https://www.pc-progress.com/Documents/Jirka/ Mallmann et al AEE 2014.pdf>. Accessed: Jan. 10, 2018. doi: 10.1016/j.agee.2014.06.024

MIRMONSEF, H. et al. Effects of an aged copper contamination on distribution of earthworms, reproduction and cocoon hatchability. Ecotoxicology and Environmental Safety, v.135, p. 267-275, 2017. Available from: <https://www.sciencedirect.com/science/ article/pii/S0147651316304146>. Accessed: Jan. 16, 2017. doi: 10.1016/j.ecoenv.2016.10.012.

MOREIRA, S. G. et al. Chemical forms in soil and availability of manganese and zinc to soybean in soil under different tillage systems. Soil and Tillage Research, v. 163, p. 41-53, 2016. Available from: <https://www.sciencedirect.com/science/article/ pii/S0167198716300769>. Accessed: Jan. 07, 2018. doi: 10.1016/j. still.2016.05.007.

MURPHY, J.; RILEY, J. P.A Modified single solution method for determination of phosphate in natural waters. Analytica Chimica Acta, v. 27, p. 31-36, 1962. Available from: <https:// www.sciencedirect.com/science/article/pii/S0003267000884445>. Accessed: Feb. 03, 2017. doi: 10.1016/S0003-2670(00)88444-5.

OLIVA, S. R. et al. Uptake, localization and physiological changes in Erica andevalencis. Plant and Soil, v. 328, p. 411-420, 2010. Available from: <https://ink.springer.com/article/10.1007/ s11104-009-0121-z>. Accessed: Apr. 14, 2018. doi: 10.1007/ s11104-009-0121-z.

PERLATTI, F. et al. Copper accumulation and changes in soil physical-chemical properties promoted by native plants in an abandoned mine site in northeastern Brazil: Implications for restoration of mine sites. Ecological Engineering, v. 82, p. 103111, 2015. Available from: <https://www.sciencedirect.com/ science/article/abs/pii/S0925857415002116>. Accessed: Jun. 17, 2018. doi: 10.1016/j.ecoleng.2015.04.085.

PUGA, A. P. et al. Cadmium, lead, and zinc mobility and plant uptake in a mine soil amended with sugarcane straw biochar. Environmental Science and Pollution Research, v.22, p. 1760617614, 2015. Available from: <https://link.springer.com/article/1 0.1007\%2Fs11356-015-4977-6>. Accessed: Sept. 07, 2018. doi: 10.1007/s11356-015-4977-6.

RODRIGUES, A. C. D. et al. Response Mechanisms of Plants to Heavy Metal Pollution: Possibility of Using Macrophytes for Remediation of Contaminated Aquatic Environments. Revista 
Virtual de Química, v.8, p.262-276, 2016. Available from: <http:// rvq.sbq.org.br/imagebank/pdf/v8n1a18.pdf>. Accessed: Jan. 15, 2018. doi: 10.5935/1984-6835.20160017.

RUSCITTI, M.. et al. Improvement of copper stress tolerance in pepper plants (Capsicum annuum L.) by inoculation with arbuscular mycorrhizal fungi. Theoretical and Experimental Plant Physiology, v. 29, p. 37-49. 2017. Available from: <https:// link.springer.com/content/pdf/10.1007\%2Fs40626-016-0081-7. pdf $>$. Accessed: Jan. 15, 2018. doi: 10.1007/s40626-016-0081-7.

SANTANA, N. A. et al. Vermicompost dose and mycorrhization determine the efficiency of copper phytoremediation by Canavalia ensiformis. Environmental Science and Pollution Research, p. 1-15, 2018. Available from: < https://link.springer.com/article/1 0.1007\%2Fs11356-018-1533-1>. Accessed: Nov. 12, 2018. doi: $10.1007 / \mathrm{s} 11356-018-1533-1$.

SANTIBÁÑEZ, C. et al. Phytostabilization of copper mine tailings with biosolids: Implications for metal uptake and productivity of Lolium perenne. Science of Total Environment, v.395, v.1, p.1-10, 2008. Available from: <https:/www.sciencedirect.com/ science/article/pii/S0048969708000065?via\%3Dihub>. Accessed: Nov. 13, 2018. doi: 10.1016/j.scitotenv.2007.12.033.

TEDESCO, M. J. et al. Análises de solo, planta e outros materiais. 2. ed. Porto Alegre, Universidade Federal do Rio Grande do Sul, 1995. 174p.
TIECHER, T. L. et al. Forms and accumulation of copper and zinc in a sandy typichapludalf soil after long-term application of pig slurry and deep litter. Revista Brasileira de Ciência do Solo, v. 37, p. 812-824, 2013. Available from: $<$ http://www.scielo.br/scielo.php?script=sci arttext\&pid=S0100-06832013000300028>. Accessed: Nov. 13, 2017. doi: 10.1590/S0100-06832013000300028.

TIECHER, T. L. et al. Effects of zinc addition to a coppercontaminated vineyard soil on sorption of $\mathrm{Zn}$ by soil and plant physiological responses. Ecotoxicology and Environmental Safety, v. 129, p. 109-119, 2016. Available from: <https://www.sciencedirect.com/science/article/ pii/S0147651316300768>. Accessed: Sept. 19, 2018. doi: 10.1016/j.ecoenv.2016.03.016.

YRUELA, I. Copper in plants. Brazilian Journal of Plant Physiology, v. 171, p.145-156. 2005. Available from: $<$ http://www.scielo.br/scielo.php?script=sci_arttext\&pid $=$ S1677-04202005000100012>. Accessed: Jan. 13, 2018. doi: 10.1590/S1677-04202005000100012.

$\mathrm{XU}$, Y. et al. Toxicity of sulfadiazine and copper and their interaction to wheat (Triticuma estivum L.) seedlings. Ecotoxicology and Environmental Safety, v. 142, p. 250-256. 2017. Available from: <https://www.sciencedirect.com/science/ article/pii/S014765131730204X?via\%3Dihub>. Accessed: Sept. 10, 2018. doi: 10.1016/j.ecoenv.2017.04.007. 